\title{
Achieving a Sustained Competitive Advantage in the South African Telecommunications Sector
}

\author{
Mfanasibili Ngwenya \\ Graduate School of Technology Management, Faculty of Engineering, \\ the Built Environment and Information Technology, University of Pretoria, South Africa
}

Copyright $\mathrm{C} 2017$ by authors, all rights reserved. Authors agree that this article remains permanently open access under the terms of the Creative Commons Attribution License 4.0 International License

\begin{abstract}
The sustainability of South African telecommunications companies is under threat. Such threats are as a result new regulations that allowed influx of new entrant in the form of ISPs (Internet Service Providers) and the emergent of over-the-top (OTT) applications in recent years. This research seeks to understand the factors that influence a sustained competitive advantage despite all the challenges in the telecommunications industry in South Africa. The research explained the relationship that exist between service quality and sustained competitive advantage as well as the relationship that exist between intellectual capital and sustained competitive advantage. The study looked at the influence from both an internal perspective and external perspective. The internal perspective analysed the three constructs that make up intellectual capital namely; human capital, structural capital and relational capital. The external perspective used the SERVQUAL model to analyse how customers perceive services they expect to get from the telco providers and how they perceive the services after an encounter with the telco provider. The SERVQUAL model looks at five constructs of service quality namely; tangibility, reliability, responsiveness, assurance and empathy. The results of the study show that in the telco industry, relational capital is the most important dimension of intellectual capital followed by human capital, with structural capital coming up last. On the service quality variable, the research shows that customers see assurance as the most important dimension of service quality. With this in mind, the telco companies need to focus on their relational capital and human capital which includes customers and suppliers. They also need to focus on the assurance and responsiveness part of service quality. These variables will then influence future behaviour of customers (external view) as well allow employees to forge relationships that are long lasting and develop skills continuously (internal view). These dimensions are critical for the telco providers to achieve a sustained competitive advantage.
\end{abstract}

Keywords Service Quality, SERVQUAL, Competitive Advantage, Intellectual Capital, Relational Capital,
Structural Capital, Human Capital, Tangibility, Assurance, Responsiveness, Reliability, Empathy

\section{Introduction}

The sustainability of most companies remains under threat unless conscious steps are taken by management to remain relevant. This is especially true in the telecommunications industry where information moves at the speed of light from one part of the world to any destination, and technological changes happen at the blink of an eye. The over-the-top (OTT) applications have increased tremendously in recent years with the introduction of smart phones and tablets. An OTT application is any application or service that provides a product over the Internet and bypasses traditional ways. Services that come over-the-top are most typically related to media and communication and are more often than not lower in cost than the traditional methods of delivery. The South African telecommunications sector is not immune to these challenges. Other challenges are caused by changes in regulations, entry of new players, and more disruptive innovations. This kind of competition comes with disruptive innovations in a sense that such innovations threaten traditional revenue streams of telco companies.

This research attempts to answer the effect of intellectual capital and service quality to sustained competitive advantage despite the challenges mentioned above. The dimensions that make up intellectual capital are examined and the most influential dimension is determined. On the other hand, the five dimensions that contribute to service quality (SQ) are discussed and the most significant applicable in the telecommunications industry in South Africa from a customer perspective is tested. The study assumes that a combination of superior intellectual capital (IC) of a company and great service should lead to sustainable competitive advantage. However, the study also takes cognizance that each of the constructs that contribute to 
either IC or SQ do not have the same influence from industry to industry within the services sector. The question then arise as to the most important constructs, be it from IC or SQ side, in the South African telecommunication industry. This paper seeks to explain how companies can move from "temporary competitive advantage" to "sustained competitive advantage" regardless of changing regulatory environments in the telecommunications sector.

\subsection{Problem Statement}

While telecommunications companies had been quick to react to previous game changing developments such as the internet explosion and the emergence of cellular mobile communications in the 1990 s, they seem to have been caught napping in the face of the newest challenge to their revenues in the hands of over-the-top service providers [1]. The fact that technological changes happen very fast in this $21 \mathrm{st}$ century mean that companies are in danger of becoming irrelevant as a result of disruptive innovation. For example the introduction of WhatsApp in 2009 meant that the use of traditional SMS (Short Message Service) has been declining ever since. Recently, WhatsApp followed the likes of Skype, Facebook and many more providers in making it possible to make voice calls on the same application using data. This is disruptive to the traditional voice services. The research explores the extent at which intellectual capital and service quality play a role in creating and sustaining a competitive advantage despite all these disruptive innovations and regulatory changes. Customers' behavioural intentions as a result to service quality are analyzed. In order to address the research problem effectively we have to develop the hypothesis in the next section.

\subsection{Hypothesis Development}

The model below assumes that intellectual capital and service quality contributes to the sustained competitive advantage of companies. The diagram below summaries the different hypotheses that support the proposed model.

Which predictors are significant towards achieving sustained competitive advantage?

- Hypothesis 1 (H1): Superior Intellectual Capital in the telecommunications company leads to sustained competitive advantage. Sustained competitive advantage can be achieved by developing the company's intellectual capital.

- $\quad$ H1 (a) - relational capital is the most significant contributor towards superior intellectual capital

- H1 (b) - structural capital is important in the achieving superior intellectual capital

- $\quad H 1$ (c) - human capital is critical in achieving a superior intellectual capital

- Hypothesis 2 (H2): Differentiated Service Quality leads to sustained competitive advantage.

- $\quad \mathrm{H} 2$ (a) - there is a positive correlation between tangibility and service quality

- $\quad \mathrm{H} 2$ (b) - there is a positive correlation between responsiveness and service quality.

- $\quad \mathrm{H} 2$ (c) - there is a positive correlation between empathy and service quality

- $\quad H 2$ (d) - there is a positive correlation between assurance and service quality

- $\mathrm{H} 2$ (e) - there is positive greater correlation between reliability and service quality

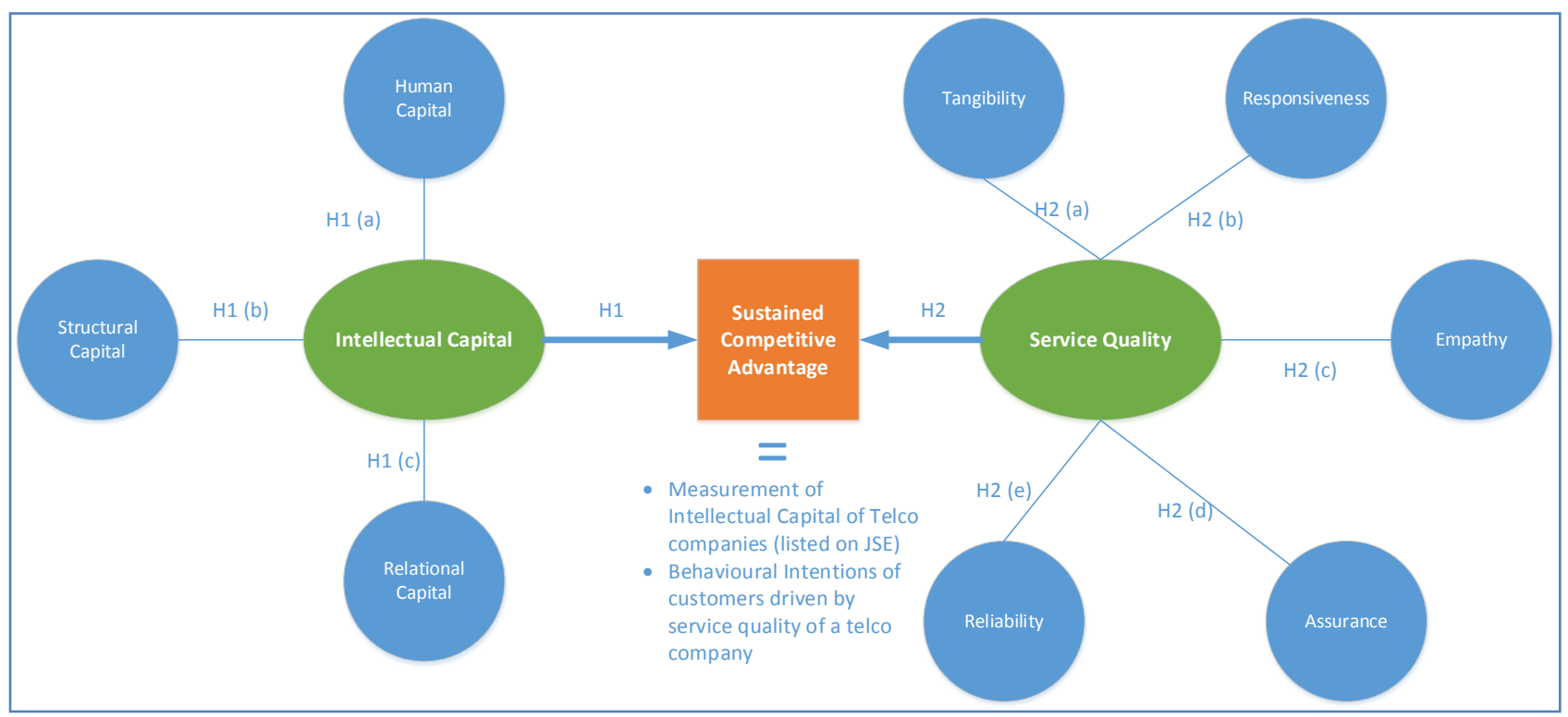

Figure 1. Hypothesis Development - Contributing Constructs 


\section{Literature Review}

\subsection{Competitive Advantage Overview}

The lifeblood of companies is in gaining a competitive advantage in the industry in which they operate. Porter [2] says that to have a sustainable competitive advantage a company needs to create value for its customers, select markets in which it can excel and presents a moving target to its competitors through improving position in a continuous manner. Chahal and Bakshi [3], describe competitive advantage as an outcome which is provided by rare, valuable and unique human resources, customer relationships and systems which provide a company with sustainable competitive position. On the other hand Kay [4] explained competitive advantage as an advantage that a company has in the market place that result in superior financial performance.

Ma [5] refers to competitive advantage as the comparative positional superiority in the marketplace that leads an organization to outperform its rivals by providing such strategies that are difficult to be copied. He further stipulated competitive advantage as the result that is derived in the form of valuable, rare, difficult to substitute and difficult to imitate resources. O'Brien and Kok [6], ascertain that companies will have to do more than just offer the services to enjoy sustainable profits in the future. That means they need to also focus deeply on the quality of that service, the delivery method thereof and the future behaviour of customers. Bontis [7] relates sustained competitive advantage with human capital. He remarked that the more the unique competence an individual possesses in an organization, the more is the competitive edge of that organization because valuable and rare employees create more value. While this may be true, it is just one aspect of the intellectual capital. While it is true that employees can assist a company by adding value using their rare and unique characteristics, there is also structural capital, and relational capital that needs to be taken into consideration.

\subsection{The Concept of Service Quality}

Service quality leads to customer satisfaction which in turn has a positive impact on customer word-of-mouth, attitudinal loyalty, and purchase intentions [8]. Service organisations have begun focusing on the customer perceptions of service quality because it helps in developing strategies that lead to customer satisfaction [9]. Various studies that focused on a link between satisfaction and quality argued for different views in terms of relationship. While some scholars say that quality leads to satisfaction [10], [11], other prior scholars argue that satisfaction leads to quality [12]. Parasuraman, et al. [13], mention that quality and satisfaction are determined by the same attributes. The latter scholars see customer satisfaction as transaction specific, meaning consumers get satisfied with a specific aspect of service while perceived service quality is a global judgement or attitude to a service.

Negi [11], points out that service quality is significantly associated with and contributes to the overall satisfaction. His view is from a mobile telco consumers point of view and we assume that view is applicable across the telco industry. Saravanan and Rao [9], ascertain that customer satisfaction is based on the level of service quality delivered by the service providers. Cicerone, et al. [14], agree and further mention that this is determined by the consumer's cumulative experiences at all of the points of contact with company. As much as there is minimal contact in cinsuming telco services, it should be noted that the little contacts via service centres and cellular shops can have significant impact in as far as service quality perception is concerned and hence customer satisfaction. Wicks and Roethlein [15], says that the link between service quality and customer satisfaction cannot be ignored and that the importance of customer satisfaction when defining quality is very important.

While all these studies confirm a relationship between service quality and customer satisfaction, Asubonteng, et al. [16], say that there is no agreement on the exact kind of relationship between the two constructs and points of out that most researchers agree that service quality and customer satisfaction have attributes that are measurable.

Lai, et al. [17] mention that a company cannot achieve success in today's business environment without delivering superior service quality. If the service is superior, companies can even charge more than their competitors. Excellent service can be seen as profit strategy as the company can gain new customers, keep existing customers while getting new business from them, and charge premium prices. Saravanan and Rao [9], found that the above factors all lead to improved perceived service quality, customer satisfaction and loyalty from the customer's perspective. Most scholars agree that service quality is a very complex topic and is define it using five dimensions namely; reliability, responsiveness, assurance, empathy, and tangibles [18], [13], [11].

\subsection{Models to Measure Service Quality}

It is very important to measure service quality because it allows for comparisons before and after changes, identifies quality related problems, and helps in developing clear standards for service delivery Some of the models used to measure service quality are discussed below:

Gronroos Model - Ghotbabadi, et al. [19], attributes the early conceptualization of service quality to Christian Gronroos from the early 1980s. The model defined service quality by technical or outcome (what consumer receive) and functional or process related (how consumer receive the service) dimensions. Ghotbabadi, et al. [20], say that the model is based on disconfirmation paradigm by comparing perceived performance and expected service. More subsequent scholars followed Grönroos [21]'s definition. Rust and Oliver [22] defines this model by three components 
namely; service product (i.e., technical quality), service delivery (i.e., functional quality), and service environment. The shortfall here was that they did not really test the model.

Haywood-Farmer Service Quality Model - The Haywood-Farmer service quality model dates back to the late 1980s. Haywood-Farmer [23], believes that the choice of elements from each of these three sets of service quality factors is an important, strategic managerial decision. The relative degrees of labour intensity, service process customisation, and contact and interaction between the customer and the service process, partially determine an appropriate mix.

The more a service requires contact with customers, the more labour intensive it becomes. In such a cases, a company needs to pay more attention in making sure that the personnel providing the service on behalf of the company behave appropriately. The voice and data service from the telco providers is a typical example of a service that is not labour intensive.

The three service attributes identified by Haywood-Farmer [23] can also not be directly compared with the three service dimensions of Grönroos [21] and the five dimensions of Parasuraman, et al. [13].

The SERVQUAL Model - The SERVQUAL instrument is based on the gap theory [13]. The model was developed after carrying out a study on four service settings: retail banking, credit card services, repair and maintenance of electrical appliances, and long-distance telephone services. This is more of an attitude measure. What this model strives to measure is the consumer perception of the service quality which depends on the size of the gap between expected service and perceived service which in turn, depends on the gaps under the control of the service provider such as delivery of service and marketing. This model suggests that a consumer's perception of service quality is a function of the difference between customer's expectations about the performance of a general class of service providers and the customer's assessment of the actual performance of a specific service company within that class [12]. The original SERVQUAL instrument included two 22-item sections that intended to measure the following [13]; customer expectations for various aspects of service quality customer perceptions of the service they actually received from the focal service organization.

Researchers have used the SERVQAUL instrument for a number of years. Lai, et al. [17] confirmed that the SERVQUAL instrument is a valid and valuable tool to measure service quality in the service industry, including the telecommunications sector. To measure service gaps in organizations there has to be a continuous customer feedback [18]. This section defines the five gaps on service quality as articulated by Ladhari [8], Fitzsimmons, et al. [18] and Subramaniam and Youndt [24].

The SERVPERF Model - The SERVPERF model was developed by Cronin Jr and Taylor [12]. This model uses the performance approach method which measures service quality based on customer's overall feeling towards service. This model is good to measure service quality but does not provide information on how customers will prefer service to be in order for service providers to make improvements. The SERVPERF was derived from the SERVQUAL model by dropping the expectations and measuring service quality 40 perceptions just by evaluating the customer's the overall feeling towards the service. Implicitly the SERVPERF model assesses customers experience based on the same attributes as the SERVQUAL and conforms more closely on the implications of satisfaction and attitude literature [12]. SERVPERF became an alternative measurement scale of SERVQUAL. SERVPERF was constituted with a different point of view and called perception only model.

Brady and Cronin Service Quality Model - Brady and Cronin Jr [25], suggested a new model for measuring service quality. They used a seven-point Likert scale to measure the consumers' attitudes towards the items under the dimensions. Leisen Pollack [26], mentioned that in the SERVQUAL measurement, service outcomes were not clearly considered, but on the other hand Brady and Cronin's model seems to fill this void. Caro and Garcia [27] used this model in their empirical research for measuring perceived service quality in urgent transport service industry and they emphasized this hierarchical conceptualized and multidimensional model was a combining of Rust and Oliver [22] and Dabholkar, et al. [28] hierarchical RSQS model. Brady and Cronin Jr [25], saw this model as an improvement by to the SERVQUAL model by specifying what is needed to be reliable, responsive, empathic, assured and tangible. In addition, the model accept multilevel service quality perceptions and multidimensional by Dabholkar, et al. [28].

Evaluated Performance model - Teas [29], developed the evaluated performance model (EP) in order to overcome some of the problems associated with the gap in conceptualization of service quality $[13,21]$. This model measures the gap between perceived performance and the ideal amount of a feature, but not customers expectation. He argues that an examination indicates that the P-E (perception - expectation) framework is of questionable validity because of conceptual and definitional problems involving the conceptual definition of expectations, theoretical justification of the expectations component of the P-E framework, and measurement validity of the expectation. He then revised expectation measures specified in the published service quality literature to ideal amounts of the service attributes. The idea was to solve some of the criticism of some previous models. In telecommunications, service quality has become increasingly important as telecommunication companies face stiff competition driven by new entrants and substitute services. If the existing telecommunications company are serious about gaining or re-gaining a competitive advantage, it is of paramount importance that they need to improve service quality to differentiate their services from those of their competitors. The assessment of service quality is made during the service 
delivery process [18].

\subsection{The Concept of Intellectual Capital}

Sullivan [30], conceptualised intellectual capital in terms of competencies and relationships. He described intellectual capital as an intangible asset composite of human competencies, knowledge, ability, skills, experience and customer relationships that provide an organisation with superior position in the market. Barney [31], says that intellectual capital is one of the critical sources for an organisation to gain competitive advantage. And according to Edvinsson and Malone [32], intellectual capital encompasses the applied experience, organizational technology, customer relationships and professional skills that provide a company with a competitive advantage in the market. If we analyse the definition from all these scholars we can say that they agree broadly on the definition of intellectual capital. The common view is that of competencies (human capital), organizational structures (structural capital), and relationships (relational capital) all contribute towards competitive advantage. If they all contribute towards a company's competitive advantage, we need to understand the most influential of them all. We also need to understand how they can all contribute towards taking a company from a temporary competitive advantage to a sustained competitive advantage. I will be approaching intellectual capital with these definitions in mind as they capture the essence what intellectual capital is. Out of the three components of intellectual components we need to understand the most influential of the three in the telco industry. Some scholars believe that intellectual capital leads to competitive advantage but differ on which component of intellectual capital is more influential. These differences may result from the field being studied at the time. Hence, the paper intends to confirm the role of human, relational and structural capital in predicting sustainable competitive advantage in the telco sector in South Africa. The next section discussed the three components of intellectual capital.

Human Capital - The human capital component is defined as the combined knowledge, skill, innovativeness, and ability of the company's individual employees to meet the task at hand. It also includes the company's values, culture, and philosophy. Some researchers have argued that human capital is embedded in employees and not in organizations, and can be developed through training and education [33]. Elias and Scarbrough [34] and Ulrich [35] pointed that human capital has two determinants namely; employees' capabilities and their commitments. However, this research will focus on the definition that it is a summation of employees' knowledge, skills, capabilities, experience, attitude, wisdom, creativities, and commitments, etc., and was embedded in employees not in organizations [32], [36]. While I intend using the above definition of human capital, this does not in any way answer the question around its level of influence toward the overall intellectual capital in telco companies. Auw [37], believes that human capital is more significant in influencing competitive advantage and remarked that it is the employees' proficiency, skills, experience and capabilities which lead to competitive advantage in organisations. While I agree with the fact that the telco needs very highly skilled people but are those individuals the drivers of business and its sustainability? While this may be the force behind the human intellect and innovation of a telco company and a definite contributor toward competitive advantage, it doesn't necessarily mean it drives the sustainability or the long term competitive advantage of a company.

Johnson [38], also mentioned that that human capital is the lifeblood of the concept of Intellectual Capital. His argument is that in human capital, human ideas and innovations emerge. His view was from technology management point of view. Dzinkowski [39], agrees by mentioning that human capital has a positive effect on competitive advantage. Salehi, et al. [40], say that human capital is the most important asset in a company and is a source of innovation and strategic renewal. They say that it is a sum of technical expertise, leadership ability, risk-taking, and problem solving ability. While I agree on the importance of human capital especially in the technology space, the question still arises if it is the driving force for sustained competitive advantage. While Dzinkowski [39]'s view was from management accounting company's point of view, this may not necessarily be true in other service industries, including the telecommunications industry. According to Mojtahedi and Ashrafipour [41], some of the knowledge that exist within a company can be unique to individuals while some can be generic. They make mention of such attributes as innovation capacity, creativity, knowhow and previous experience, teamwork capacity, employee flexibility, tolerance for ambiguity, motivation, satisfaction, learning capacity, loyalty, formal training and education.

Structural Capital - Subramaniam and Youndt [24], found that out of all the three components of intellectual capital, structural capital plays significant role in gaining competitive advantage which consequently leads to business performance. This is in clear contrast to other scholars including Dzinkowski [39] and Johnson [38]. It is true that structural capital allows for the creation of wealth through the transformation of the work of human capital. It is defined by Al-Jaradat, et al. [42] and bin Ahmad and Mushraf [43] as the structural ability of the firm to utilize human intellect and innovation to create wealth. They further say that it includes the hardware, software, databases, organizational structure, patents, trademarks, and everything else of organizational capability that supports those employees' productivity. Put differently, it is everything that gets left behind at the office when employees go home.

Relational Capital - In the case of the telco industry I have hypothesized that the most influential intellectual capital is relational capital. While I hypothesized that it is the 
most influential, it is important to understand that it is not sustainable on its own. In other words, a telco company cannot just depend on relationships. It is a very high-tech industry and the importance of human capital cannot be over-emphasized. The point is that relationships should bring the business, and the technical skills should assist in delivering superior service and support thereof through highly skilled individuals. These individuals will be able to work together through proper structures and processes. Relational capital is defined as the ability of the firm to interact with the business community. Al-Jaradat, et al. [42], believes that the strongest component is relational capital and thus in direct contrast to Johnson [38], Dzinkowski [39] and Subramaniam and Youndt [24]. Chen [44], agrees with the idea of having relational capital as being the most influential. These scholars ascertain that the reason for relational capital being the most influential component is because robust relationships with the customers can help a company to sustain and survive in the market. They further agree that relational capital possess high potential to create competitive advantage by collaborating with other organisations through knowledge sharing routines and inter-organisational connectedness.

\subsection{Models to Measure Intellectual Capital}

A lot of models have been developed in trying to measure and manage intellectual capital. Some of them are listed below and will be further discussed below:

The Scandia Navigator - the Skandia Navigator is one of the models that attempt to measure a company's performance and intangible assets value. The model derives its names from the company Skandia where it was first developed. It was developed by the then Chief Architect Leif Edvinson [45]. The company initially developed its Intellectual Capital report in 1985 inside the company. In 1994, the company's financial report to the shareholders was accompanied by an Intellectual Capital report [46]. This model is said to be having a dynamic and holistic Intellectual Capital reporting and has five areas of focus namely; financial, customer, process, renewal and development, and human capital. Salehi, et al. [40], says that this model integrates the assumptions about intellectual capital that reflects the difference between the book and market value of a company. This tool is closely related to the balance scorecard in the way it groups the financial and non-financial indicators.

The Intellectual Capital Index - The Intellectual Capital Index attempts to consolidate all the different individual indicators into a single index, and to correlate the changes in intellectual capital with changes in the market [40, 47]. According to these authors, second generation practices still seek "to improve the visualization of the value creating processes of the company so that they can be managed comprehensively and create a bottom-line for Intellectual Capital. This synthesis allows managers to assess the intangible assets or intellectual capital of a company holistically. Roos, et al. [47], says that the first generation practices give information only on the single components of intellectual capital. On the other hand a summary index further provides an immediate improvement to having long lists of individual indicators because it requires companies to understand the priorities and relationships that exist between their different measures.

The Balance Scorecard - This model seeks to balance the financial perspective by considering internal business processes and external outcomes of the business. The balance scorecard was developed by Kaplan and Norton [48] and they mentioned that it retains traditional financial measures. They believed that if companies were to improve the management of their intangible assets, they had to integrate the measurement of intangible assets into their management systems. The aim of the Balanced Scorecard is to give managers a comprehensive view of the business and allow them to focus on critical areas. The concept of the balance scorercard is based on the assumption that the efficient use of investment capital is no longer the key determinant of competitive advantage, and that soft factors such as intellectual capital and knowledge creation are increasingly becoming more important [49].

However, some scholars have argued that financial measures tell the story of past events [50, 51, 52]. They further ascertain that this is only enough for the industrial age companies for which investments in long-term capabilities and customer relationships were not critical for success. Therefore, it means that these financial measures are inadequate in the information age. They further say that it is only useful for guiding and evaluating the journey that the information age companies must make to create future value through investment in customers, suppliers, employees, processes, technology, and innovation [53]. The balance scorecard considers the customer, financial, internal business processes and the learning and growth perspectives combined with the company's vision and strategy. Just like the Skandia Navigator, the balance scorecard group the financial and non-financial indicators. Since its inception, the balance scorecard has become a model for many of the reporting systems that include non-financial measures.

The Intangible Assets Monitor - The Intangible Asset Monitor was developed by Karl Erik Sveiby as a presentation format that displays indicators for internal management information purposes [54]. Bukowitz, et al. [55], mention that the Intangible Assets Monitor assumes that people are the only true agents in business. The authors say that it is the individuals that create structures as a form of self-expression and these structures are regarded as part of the knowledge base. While I'm in agreement with the authors with regard to creating structures, it is also true that it is the individuals that can forge lasting relationships with customers, partners and/or suppliers. This model works best in knowledge-intensive organisations. The telco industry strive on information and knowledge. Such information and 
knowledge range from core technical skills to market intelligence.

Erik Sveiby [54], further advises companies to develop one or two indicators for each intangible asset and under each of the measurement groups. The Intangible Assets Monitor is a valuable contribution to the debate on Intellectual Capital and especially emphasises the internal perspective. This tool is should provide managers with a meaningful way to communicate information on intangible assets. While this is an appealing approach to measure intellectual capital, its downside is that it is not clear as how to integrate it into any broader performance measurement frameworks in order to establish the link between intangible performance drivers and performance outcomes which become increasingly important [56].

Economic Value Added (EVA) Model - The EVA (Economic Value Added) has its roots in corporate finance and was developed by Stern Stewart, a New York-based consultancy [57]. It is also known as economic profit [58]. The EVA's main rational is to maximize shareholders' value and the effective use of capital. This should be reflected in all of the decisions of all levels of company. It is is the most recent method of organizational performance evaluation. Its focus is on maximization of shareholder wealth. In other words, EVA is a measure of whether the intellectual capital of a company has been effective or not. EVA is a substitute metric for intellectual capital and provides accurate information about the effect of Intellectual Capital on business performance [59].

It is a comprehensive performance measure that uses the variables of capital budgeting, financial planning, goal setting, performance measurement, shareholder communication, and incentive compensation to properly account for all ways in which corporate value can be added or lost [60]. Bontis, et al. [60] mention that EVA has gained widespread acceptance in the financial community and can increase the legitimacy of a company in the eyes of financial markets, as a valuable measure of corporate value-creation or destruction over a given period. According to Lehn and Makhija [61], the EVA model has attracted a lot of attention over the years from both scholars and practitioners. They further say that such attention comes from the idea that the models attempt to measure the value created or destroyed by a company by subtracting a capital employed from the after tax profit. This is clearly a step further from traditional accounting in measuring performance of a company.

The EVA model is not only used as performance measures but are also recommended by some as metrics for executive compensation plans and the development of corporate strategies $[62,63,64,65]$.

\section{Research Design and Methodology}

The research objective of this study focuses on telco companies in South Africa looking at both the internal perspective and external perspective. In the external perspective, questionnaires are used to assess consumers' satisfaction with the assumption that the level of satisfaction informs future behavioural intentions by customers and thus leading to long term competitive advantage. Different models of measuring service quality have been discussed and the SERQUAL model is chosen as this model is widely used by scholars and is said to provide data of high reliability and validity.

In the internal perspective, the primary data is obtained through structured interviews and is used in assessing intellectual capital so as to understand its impact on competitive advantage as well as to understand the level of significance between the three constructs of intellectual capital. The primary data input for assessment of intellectual capital is obtained from the managers of general employees and managers and executives from sales, customer solutions design, product management, supply chain management department, marketing, and human resources departments. In addition, I seek to ensure that my cases reflects a range of workforce skill-sets. Given my concern with management practice, I include the main telco companies that are directly affected by the ever changing landscape. None of the companies have a clear system for the collection of data on intellectual capital and thus I had to structure my questions such that I get as much information on all spheres of intellectual capital.

Within each company, I interviewed three or four respondents who play a key role in the development and implementation of their approach to intellectual capital evaluation. The final sample in this part of the study thus comes from 20 senior managers from the five telecoms companies (Vodacom, MTN, Cell C, Neotel and Telkom). Given variations in the scope of initiatives, size of organisation and the access made available by the company, the actual number of interviews varies from one company to another. In each case, however, interviews lasted around one-and-a-half hours (often longer) and were all conducted face to face. Each company has a minimum of three respondents. Interviews are conducted in a structured manner, revolving around a set of core themes based on the overall research questions.

The external point of view side of the research is conducted using structured questionnaires that are designed using the SERVQUAL model and this makes it objective. In the case of internal point of view, the research is conducted using primary data from structured interviews. The study has a self-completion questionnaire surveys whereby respondents were given the hard copy of the questionnaire to answer. This happened over a period of two months. The idea of using hard copies is to make sure that I get as much responses as possible. Each respondent was asked to respond within a period of two weeks and these hard copies were thus physically collected. The respondents were randomly chosen from a group of students to working class individuals and that ranged from the ages of 18 years to 63 years old. 
Basically, a total of 150 questionnaires was given in hard copy to consumers of telco services from across the five telco companies namely; Telkom, Neotel, Vodacom, Cell C and MTN. The data is collected using a seven-point Likert-scale, from 1 (strongly disagree) to 7 (strongly agree). These questions are answered using quantifiable data collected from respondents and this enable us come out with findings and conclusions on how customers perceive service quality and what dimensions are more important from a customer's point of view. The questionnaires also include questions regarding respondent demographics. The SERVQUAL instrument with 22 items is used on the questionnaire. The effective response rate was $85.3 \%$ which is determined by calculating those who responded within the specified time, which happened mostly happened when I followed up with each individual.

Service Quality Variable: - to analyse the service quality variable the SERVQUAL intrument model enables us to obtain answers from consumers about their perceptions and expectations. Data collected from these respondents is then analysed using SPSS software and thereafter, we are able to answer our research questions. This research is quantitative in nature and the use of SPSS software help us to determine the validity of collected data. The data collected allows us to find the most common dimensions of service quality applicable in the telco services sector. That is determined by consumer expectations.

Intellectual Capital Variable:- None of the companies have a clear system for the collection of data on intellectual capital. Each of the elements of Intellectual Capital constructs are rated between a Scale of 1 to 10 whereby 1 referred to the least important element and 10 referred the most important element. The average score between all three constructs of intellectual capital is then obtained.

\section{Results (Data Gathered and Analysis)}

\subsection{Service Quality (External View)}

The ability of service quality to be considered as a source of competitive advantage is one of the objectives of this study. Parasuraman, et al. [13] suggested that service quality can be used as a source for competitive advantage. For this purpose, behavioural intentions of the consumers of all the companies were tested in order to be able to draw comparative analysis of the users of different service providers. The next section lays the foundation of the variables used in the study of service quality.

\section{Coding}

Table 1. Coding Table

\begin{tabular}{|c|c|c|c|}
\hline \multirow{4}{*}{ Tangibles } & TA & TA1 & The telco service provider has up-to-date equipment \\
\hline & & TA2 & $\begin{array}{l}\text { Your main telco service provider's physical facilities are visually appealing (e.g. customer walk-in service } \\
\text { centres, shops, etc.) }\end{array}$ \\
\hline & & TA3 & Your telco service provider's employees are well dressed and appear neat \\
\hline & & TA4 & $\begin{array}{l}\text { The appearance of the physical facilities of your telco service provider's is in keeping with the type of } \\
\text { service provided }\end{array}$ \\
\hline \multirow[t]{5}{*}{ Reliability } & RL & RL1 & When your telco service provider's promise to do something by a certain time, it does so. \\
\hline & & RL2 & When you have problems, your telco service provider is sympathetic and reassuring. \\
\hline & & RL3 & Your telco service provider is dependable. \\
\hline & & RL4 & Your telco service provider provides its services at the time it promises to do so. \\
\hline & & RL5 & Your telco service provider keeps its records accurately. \\
\hline \multirow[t]{4}{*}{ Responsiveness } & $\mathrm{RN}$ & RN1 & Your telco service provider dos not tell customers exactly when services will be performed. \\
\hline & & $\mathrm{RN} 2$ & You do not receive prompt service from your telco service provider's employees. \\
\hline & & $\mathrm{RN} 3$ & Employees of your telco service provider are not always willing to help customers. \\
\hline & & RN4 & Employees of your telco service provider are too busy to respond to customer requests promptly. \\
\hline \multirow[t]{4}{*}{ Assurance } & AS & AS1 & You can trust the employees of your telco service provider. \\
\hline & & AS2 & You feel safe in your transaction with your telco service provider's employees. \\
\hline & & AS3 & Employees of your telco service provider are polite. \\
\hline & & AS4 & Employees get adequate support from your telco service provider to do their jobs well. \\
\hline \multirow[t]{5}{*}{ Empathy } & EM & EM1 & Your telco service provider does not give you individual attention. \\
\hline & & EM2 & Employees of your telco service provider do not give customers personal attention. \\
\hline & & EM3 & Employees of your telco service provider do not know what your needs are. \\
\hline & & EM4 & Your telco service provider doesn't have customers' best interests at heart. \\
\hline & & EM5 & Your telco service provider doesn't have operating hours convenient to all its customers. \\
\hline
\end{tabular}




\section{Re-coding}

$\mathrm{TA}-$ Average gap score for tangible items $=(\mathrm{TA} 1+\mathrm{TA} 2+\mathrm{TA} 3+\mathrm{TA} 4) / 4$

$\mathrm{RL}-$ Average gap score for reliability items $=(\mathrm{RL} 1+\mathrm{RL} 2+\mathrm{RL} 3+\mathrm{RL} 4+\mathrm{RL} 5) / 5$

$\mathrm{RN}$ - Average gap score for responsiveness items $=(\mathrm{RN} 1+\mathrm{RN} 2+\mathrm{RN} 3+\mathrm{RN} 4) / 4$

AS - Average gap score for assurance items $=(\mathrm{AS} 1+\mathrm{AS} 2+\mathrm{AS} 3+\mathrm{AS} 4) / 4$

$\mathrm{EM}-$ Average gap score for empathy items $=(\mathrm{EM} 1+\mathrm{EM} 2+\mathrm{EM} 3+\mathrm{EM} 4+\mathrm{EM} 5) / 5$

OSQ - Overall service quality $=(\mathrm{TA}+\mathrm{RL}+\mathrm{RN}+\mathrm{AS}+\mathrm{EM}) / 5$

To check the reliability of data items of the questionnaire Cronbach's alpha reliability test was run by using SPSS software.

\section{Service Quality Assessment in the Telco Industry}

There were 150 questionnaires that were distributed in hard copy. The responses that could be collected on time was 128 out of 150 , making a response rate of $85.3 \%$. Of the 128 responses, only 119 could be used for data analysis. The table below is the summary of the data collected across all the telco providers:

Table 2. Summary of Questionnaires Distributed and Response Rate

\begin{tabular}{|c|c|c|c|c|c|}
\hline Telco Provider & Vodacom & MTN & Cell & Neotel & Telkom \\
\hline Distributed Questionnaires to Customers n $\mathbf{1 5 0}$ & 45 & 33 & 25 & 23 & 24 \\
\hline Percentage (\%) & $30 \%$ & $22 \%$ & $17 \%$ & $15 \%$ & $16 \%$ \\
\hline Response Rate & & & & & \\
\hline Percentage (\%) & 41 & 28 & 19 & 20 & 20 \\
\hline Usable Questionnaires & $34 \%$ & $24 \%$ & $16 \%$ & $17 \%$ & $17 \%$ \\
\hline & & & & & \\
\hline
\end{tabular}

The table of results below shows data averages from the 119 usable questionnaires out of the 150 distributed questionnaires.

The computed data from the questionnaires is shown in the table below:

Table 3. Service Quality Assessment - Industry

\begin{tabular}{|c|c|c|c|c|c|c|}
\hline Dimension & Statement & $\begin{array}{l}\text { Expectation Score } \\
\text { in Percentage (E) }\end{array}$ & $\begin{array}{l}\text { Perception Score } \\
\text { in Percentage (P) }\end{array}$ & $\begin{array}{l}\text { Gap Score in } \\
\text { Percentage } \\
\text { (P-E) }\end{array}$ & $\begin{array}{l}\text { Overall } \\
\text { Gap } \\
\text { Score } \\
\end{array}$ & $\begin{array}{c}\text { Average } \\
\text { Gap }\end{array}$ \\
\hline & & Mean & Mean & & & \\
\hline \multirow[t]{5}{*}{ Tangibles (TA) } & Average & 6.175 & 5.675 & & -2 & -0.5 \\
\hline & TA1 & 6.3 & 5.6 & -0.7 & & \\
\hline & TA2 & 6.2 & 5.6 & -0.6 & & \\
\hline & TA3 & 5.7 & 5.5 & -0.2 & & \\
\hline & TA4 & 6.5 & 6 & -0.5 & & \\
\hline \multirow[t]{6}{*}{ Reliability (RL) } & Average & 6.14 & 4.26 & & -9.4 & -1.88 \\
\hline & RL1 & 6 & 4.1 & -1.9 & & \\
\hline & RL2 & 6.2 & 4.5 & -1.7 & & \\
\hline & RL3 & 6.1 & 3.9 & -2.2 & & \\
\hline & RL4 & 6.5 & 4.2 & -2.3 & & \\
\hline & RL5 & 5.9 & 4.6 & -1.3 & & \\
\hline \multirow[t]{5}{*}{ Responsiveness (RN) } & Average & 6.375 & 4.375 & & -8 & -2 \\
\hline & RN1 & 6.1 & 4.4 & -1.7 & & \\
\hline & $\mathrm{RN} 2$ & 6.3 & 4.5 & -1.8 & & \\
\hline & RN3 & 6.8 & 4.3 & -2.5 & & \\
\hline & RN4 & 6.3 & 4.3 & -2 & & \\
\hline \multirow[t]{5}{*}{ Assurance (AS) } & Average & 6.425 & 4.55 & & -7.5 & -1.875 \\
\hline & AS1 & 6.4 & 4.2 & -2.2 & & \\
\hline & AS2 & 6.5 & 4.7 & -1.8 & & \\
\hline & AS3 & 6.4 & 4.7 & -1.7 & & \\
\hline & AS4 & 6.4 & 4.6 & -1.8 & & \\
\hline \multirow[t]{6}{*}{ Empathy EM) } & Average & 6.32 & 4.46 & & -9.3 & -1.86 \\
\hline & EM1 & 6.1 & 4.5 & -1.6 & & \\
\hline & EM2 & 6.3 & 5 & -1.3 & & \\
\hline & EM3 & 6 & 4.2 & -1.8 & & \\
\hline & EM4 & 6.7 & 4.3 & -2.4 & & \\
\hline & EM5 & 6.5 & 4.3 & -2.2 & & \\
\hline
\end{tabular}


The data above addresses the external perspective (service quality) whereby there were 150 questionnaires that were distributed in hard copy. The responses that could be collected on time was 128 out of 150 , making a response rate of $85.3 \%$. Of the 128 responses, only 119 could be used for data analysis. The reliability of the data for both expectation and perception was tested using SPSS and had Cronbach's alpha of 0.75 and 0.77 respectively. The results to measure the external perspective of a telco company shows that consumers expect superior service quality. When we look at the expectations data, consumers expect a higher level of assurance in the telecommunications industry with a score of 6.425. That was ahead of reliability, which in fact came last with an average of 6.14. Assurance was closely following by responsiveness and empathy.

When it comes to the overall GAP score, the tangibles had the lowest GAP score which is a sign that what the customers expect in terms of tangible is not far off when compared to what they perceived or experienced. All the dimensions of services quality recorded a negative value which means the telco companies in South Africa are not meeting customer expectations in their service offerings. The figures are alarmingly low in as far as assurance, reliability, responsiveness and empathy is concerned:

\subsection{Intellectual Capital (Internal View)}

In the case of the internal perspective (measure of intellectual capital), the results of factor analysis showed that the questionnaires used in the interviews were enough to investigate the importance of intellectual capital with a Cronbach's alpha of 0.76 . The answers were able to explain the most dominant component of intellectual capital in the telco space. The results below show the empirical evidence from an internal perspective in as far as the influence of intellectual capital is concerned.

From the results, we see that Relational Capital is the most important aspect in the telco industry. The senior managers felt that it was more important for them to have solid relationship especially in the B2B space. Customer relations came up as the most important part of relational capital followed by supplier relations. The data shows that overall, the human capital followed relational capital in terms of significance in the telco industry. While the human capital is not the most important, it is still a very critical part in the telco industry and the data shows that it's more important than the structural capital.

Table 4. Results Ranking Intellectual Capital Constructs in the Telco space

\begin{tabular}{|c|c|c|c|}
\hline \multicolumn{2}{|c|}{ Type of Capital } & $\begin{array}{c}\text { Relative Strength in } \\
\text { Your Company (Mean) }\end{array}$ & $\begin{array}{c}\text { Average Score for } \\
\text { Each Type of } \\
\text { Capital }\end{array}$ \\
\hline \multirow{3}{*}{ Human Capital } & & $\begin{array}{c}\text { 0= less important } \\
\text { 10= very important }\end{array}$ & \multirow{2}{*}{8.88} \\
\cline { 2 - 4 } & Ideas & 8.83 & \\
\cline { 2 - 4 } & Leadership & 8.7 & \multirow{2}{*}{8.18} \\
\hline \multirow{3}{*}{ Structural Capital } & Innovation & 9.1 & \\
\cline { 2 - 4 } & Processes & 8.73 & \multirow{2}{*}{9.08} \\
\hline \multirow{3}{*}{ Relational Capital } & Culture & 7.63 & \\
\cline { 2 - 4 } & customer relations & 9.63 & \\
\cline { 2 - 4 } & supplier relations & 9.59 & \\
\cline { 2 - 4 } & community stakeholders relations & 8.01 & \\
\hline
\end{tabular}




\section{Conclusions and Recommendations}

The results show that relational capital is more important than the other two categories of intellectual capital. The interviewed top managers selected customer relations as the most important part of the relational capital and in fact, the most important attribute of all attributes tested. This shows that managers value customer loyalty and believe that it influences future behaviour and thus sustained competitive advantage. Community stakeholder relations was not considered a key relational capital attribute.

In the case of human capital which followed closely to the relational capital, the most important attribute was innovation. Senior manager insisted that in this industry whereby there's stiff competition from new entrants as well as from the existence of substitute products and services, it is critical for companies to push boundaries in as far as innovation is concerned. The consensus was that the human capital part should have personnel that are not afraid to pursue ideas that lead to innovation. Such innovation may influence the way the company deal with internal structure and processes - process innovation. While all the attributes that drive superior intellectual capital are intrinsically linked, the senior manager agreed there has to be systematic way of prioritizing the attributes in the telco and thus achieve overall sustained competitive advantage. These results show that managers prefer to focus on learning and development that will lead to future business successes.

There is a consensus between academia and practitioners that successful companies are those that continuously innovate. Information and knowledge is the engine of corporate development. Telco companies' needs to continually innovate, focus on gaining customer loyalty and forge lasting relationships with suppliers. Other constructs should not be ignored in the process but it is assumed that on the most critical constructs, the other ways will be taken care of by the great relational and human capital anyway.

\subsection{Contributions to Practice}

The results discussed represent a basis for future research that will can help telco companies develop the most critical elements to enable them to have a competitive advantage over a long period. As we live in societies that are dominated by services, it is imperative that companies differentiate themselves from a service quality point of view. It is important to understand what resonate with customers in as far as dimensions of service quality is concerned. It is also important for companies to give intangible assets the attention they deserve if they are to remain competitive over a long period of time. In the telecommunications industry, companies should focus on the most important dimensions and the study found that assurance is more important in the telecommunications industry as customers expect a certain level of assurance from their telco service providers.

When it comes to intellectual capital, the research is not prescriptive on the model to use. It is important to understand the strengths and weaknesses of each model and leverage on the strengths of more than one model to get a comprehensive view of the company's intellectual capital. After analysing the company's intellectual capital, managers are able to see if the most important dimensions in the telco are receiving the attention they deserve.

\subsection{Future Studies}

Studies in the telco industry's competitiveness is of paramount importance for the benefit of the consumers, telco providers, country and the world as a whole. In the information age, companies cannot afford to take things for granted and depend on past glory. More studies that seek to understand service quality and customer behaviour are needed. Future studies can seek to focus more on either B2B space or B2C space. It is envisaged that the results may alter when focus is given to each of these segments. When it comes to intellectual capital, models that consolidate all the strengths of each and every model needs to be developed and simplified for easier use in both academia and in practice.

Finally, the mere fact that the telco industry is a complex environment, future studies can focus on incorporating complexity theory, complexity leadership theory, and complex adaptive systems. We need to appreciate that the telco industry has all the characteristics of a complex adaptive system namely; non-linearity, dynamic behaviour, emergence as well as self-organizing. Uhl-Bien, et al. [66], defines a complex system as the one whose component parts interact with sufficient intricacy that they cannot be predicted by standard linear equations and the telco industry is unpredictable as it is influenced by politics, economics, suppliers, customers, employees, shareholders, and other stakeholders. Clearly, there are a lot of variables at work in the telco industry (which can be referred to as a system in its own right), that its overall behaviour can only be understood as an emergent consequence of the holistic sum of the myriad behaviours embedded within. Reductionism does not work with complex systems and thus a purely reductionist approach cannot be applied if we are to understand complex systems [67]. In "systems thinking" we say that the whole is more than the sum of its parts. This is even more profound in complex systems which allow certain behaviours and characteristics to emerge. There is no doubt a lot of opportunities for future research in this ever changing industry.

\section{REFERENCES}

[1] Sujata J, Sohag S, Tanu D, Chintan D, Shubham P, Sumit G. Impact of Over the Top (OTT) Services on Telecom Service Providers. Indian Journal of Science and Technology. 2015; 8(S4):145-60. 
[2] Porter ME. Competitive advantage: creating and sustaining superior performance. New York. 1985.

[3] Chahal H, Bakshi P. Examining intellectual capital and competitive advantage relationship: role of innovation and organizational learning. International Journal of Bank Marketing. 2015; 33(3):376-99.

[4] Kay J. Foundations of corporate success Oxford University Press. Oxford; 1993.

[5] Ma H. Toward global competitive advantage: Creation, competition, cooperation, and co-option. Management decision. 2004; 42(7):907-24.

[6] O'Brien J, Kok J. Business Intelligence and the telecommunications industry: can business intelligence lead to higher profits? South African Journal of Information Management. 2006; 8(3).

[7] Bontis N. Assessing knowledge assets: a review of the models used to measure intellectual capital. International journal of management reviews. 2001;3(1):41-60.

[8] Ladhari R. A review of twenty years of SERVQUAL research. International Journal of Quality and Service Sciences. 2009; 1(2):172-98.

[9] Saravanan R, Rao K. Measurement of service quality from the customer's perspective-an empirical study. Total Quality Management and Business Excellence. 2007; 18(4):435-49.

[10] McDougall GH, Levesque T. Customer satisfaction with services: putting perceived value into the equation. Journal of services marketing. 2000; 14(5):392-410.

[11] Negi R. User's perceived service quality of mobile communications: experience from Ethiopia. International Journal of Quality \& Reliability Management. 2009; 26(7):699-711.

[12] Cronin Jr JJ, Taylor SA. Measuring service quality: a reexamination and extension. The journal of marketing. 1992:55-68.

[13] Parasuraman A, Zeithaml VA, Berry LL. Servqual. Journal of retailing. 1988; 64(1):12-40.

[14] Cicerone B, Hekele A, Morado J. Stop Managing Customer Satisfaction Reactively. Industrial Management. 2009; 51(3).

[15] Wicks AM, Roethlein CJ. A satisfaction-based definition of quality. The Journal of Business and Economic Studies. 2009; $15(1): 82$.

[16] Asubonteng P, McCleary KJ, Swan JE. SERVQUAL revisited: a critical review of service quality. Journal of Services marketing. 1996; 10(6):62-81.

[17] Lai F, Hutchinson J, Li D, Bai C. An empirical assessment and application of SERVQUAL in mainland China's mobile communications industry. International Journal of Quality \& Reliability Management. 2007; 24(3):244-62.

[18] Fitzsimmons JA, Fitzsimmons MJ, Bordoloi SK. Service Management: Operations, Strategy, Information Technology. 8 ed. New York: McGraw-Hill Education; 20142014.

[19] Ghotbabadi AR, Baharun R, Feiz S, editors. A review of service quality models. 2nd International Conference on Management; 2012.
[20] Ghotbabadi AR, Feiz S, Baharun R. Service Quality Measurements: A Review. International Journal of Academic Research in Business and Social Sciences. 2015; 5(2):267.

[21] Grönroos C. A service quality model and its marketing implications. European Journal of Marketing. 1984; 18(4):36-44.

[22] Rust RT, Oliver RW. The death of advertising. Journal of Advertising. 1994; 23(4):71-7.

[23] Haywood-Farmer J. A conceptual model of service quality. International Journal of Operations \& Production Management. 1988; 8(6):19-29.

[24] Subramaniam M, Youndt MA. The influence of intellectual capital on the types of innovative capabilities. Academy of Management Journal. 2005; 48(3):450-63.

[25] Brady MK, Cronin Jr JJ. Some new thoughts on conceptualizing perceived service quality: a hierarchical approach. Journal of Marketing. 2001; 65(3):34-49.

[26] Leisen Pollack B. Linking the hierarchical service quality model to customer satisfaction and loyalty. Journal of Services marketing. 2009; 23(1):42-50.

[27] Caro LM, Garcia JAM. Measuring perceived service quality in urgent transport service. Journal of Retailing and Consumer Services. 2007; 14(1):60-72.

[28] Dabholkar PA, Thorpe DI, Rentz JO. A measure of service quality for retail stores: scale development and validation. Journal of the Academy of Marketing Science. 1995; 24(1):3-16.

[29] Teas RK. Expectations, performance evaluation, and consumers' perceptions of quality. The journal of marketing. 1993:18-34.

[30] Sullivan PH. Profiting from intellectual capital. Journal of Knowledge Management. 1999; 3(2):132-43.

[31] Barney J. 15 Firm resources and sustained competitive advantage. International Business Strategy: Theory and Practice. 2015:283.

[32] Edvinsson L, Malone MS. Intellectual Capital: Realizing Your Companyl's True Value by Finding Its Hidden Brainpower. 1997.

[33] Miller R, Wurzburg G. Investing in human capital. Organisation for Economic Cooperation and Development. The OECD Observer. 1995(193):16.

[34] Elias J, Scarbrough H. Evaluating human capital: an exploratory study of management practice. Human Resource Management Journal. 2004; 14(4):21-40.

[35] Ulrich D. A new mandate for human resources. Harvard business review. 1998; 76:124-35.

[36] Roos J, Edvinsson L, Roos G. Intellectual capital: navigating in the new business landscape: New York University Press; 1998.

[37] Auw E. Human capital, capabilities and competitive advantage. International Review of Business Research Papers. 2009; 5(5):25-36.

[38] Johnson WH. An integrative taxonomy of intellectual capital: measuring the stock and flow of intellectual capital components in the firm. International Journal of Technology Management. 1999; 18(5-8):562-75. 
[39] Dzinkowski R. The measurement and management of intellectual capital: an introduction. Management Accounting. 2000; 78(2):32-6.

[40] Salehi M, Enayati G, Javadi P. The relationship between intellectual capital with economic value added and financial performance. Iranian Journal of Management Studies. 2014; $7(2): 245$.

[41] Mojtahedi P, Ashrafipour MA. The Effects of Intellectual Capital on Economic Value Added in Malaysians Companies. Current Research Journal of Economic Theory. 2013; 5(2):20-4.

[42] Al-Jaradat OM, AL-Samraie FA, Jadallah NAH. Intellectual capital and its role in achieving competitive advantage: a field study for the Jordanian income tax service. European Journal of Scientific Research. 2012; 69(3):399-415.

[43] bin Ahmad S, Mushraf AM. The Relationship between Intellectual capital and Business Performance: An empirical study in Iraqi industry. 2011.

[44] Chen Y-S. The positive effect of green intellectual capital on competitive advantages of firms. Journal of business ethics. 2008; 77(3):271-86.

[45] Bontis N. There's a price on your head: managing intellectual capital strategically. Business Quarterly. 1996; 60: 40-78.

[46] Huseman R, Goodman J. Leading with knowledge: The nature of competition in the Twenty-First century. Thousand Oaks, CA: Sage; 1999.

[47] Roos J, Edvinsson L, Dragonetti NC. Intellectual capital: Navigating the new business landscape: Springer; 1997.

[48] Kaplan R, Norton D. The Balanced Scorecard: Measures That Drive Performance. Harvard business review. 1992.

[49] Kontić L, Čabrilo S. A strategic model for measuring intellectual capital in Serbian industrial enterprises. Economic annals. 2009; 54(183):89-117.

[50] Kaplan RS, Norton DP. The balanced scorecard: translating strategy into action: Harvard Business Press; 1996.

[51] Abernathy DJ. Thinking outside the evaluation box. Training \& Development. 1999; 53(2):18-24.

[52] Cebeci U. Fuzzy AHP-based decision support system for selecting ERP systems in textile industry by using balanced scorecard. Expert Systems with Applications. 2009; 36(5):8900-9.

[53] Fragouli E. Intellectual Capital \& Organizational Advantage: an economic approach to its valuation and measurement. Business and Management. 2015; 7(1):36-57.
[54] Erik Sveiby K. The intangible assets monitor. Journal of Human Resource Costing \& Accounting. 1997; 2(1):73-97.

[55] Bukowitz WR, Chaminade C, Jensen H, Roberts H, L Willams R. How to develop and monitor your company's intellectual capital. 2003.

[56] Marr B, Schiuma G, Neely A. Intellectual capital-defining key performance indicators for organizational knowledge assets. Business Process Management Journal. 2004; 10(5):551-69.

[57] Mouritsen J. Driving growth: economic value added versus intellectual capital. Management accounting research. 1998; 9(4):461-82.

[58] Fernandez P. EVA, economic profit and cash value added do not measure shareholder value creation. IESE business School. 2001:72-9.

[59] Ghosh S, Mondal A. Indian software and pharmaceutical sector IC and financial performance. Journal of Intellectual Capital. 2009; 10(3):369-88.

[60] Bontis N, Dragonetti NC, Jacobsen K, Roos G. The knowledge toolbox: A review of the tools available to measure and manage intangible resources. European Management Journal. 1999; 17(4):391-402.

[61] Lehn K, Makhija AK. EVA \& MVA as performance measures and signals for strategic change. Strategy \& Leadership. 1996; 24(3):34-8

[62] Lehn K, Makhija AK. EVA, accounting profits, and CEO turnover: an empirical examination, 1985-1994. Journal of applied corporate finance. 1997; 10(2):90-7.

[63] Sheikholeslami M. EVA, MVA, and CEO compensation. American Business Review. 2001; 19(1):13.

[64] Fatemi A, Desai AS, Katz JP. Wealth creation and managerial pay: MVA and EVA as determinants of executive compensation. Global Finance Journal. 2003; 14(2):159-79.

[65] Baum CL, Sarver L, Strickland T. EVA, MVA and CEO compensation: Further evidence. American Business Review. 2004; 22(2):82.

[66] Uhl-Bien M, Marion R, McKelvey B. Complexity leadership theory: Shifting leadership from the industrial age to the knowledge era. The leadership quarterly. 2007; 18(4):298-318

[67] Uhl-Bien M, Marion R. Complexity leadership in bureaucratic forms of organizing: A meso model. The leadership quarterly. 2009; 20(4):631-50. 